\title{
LONG-TERM OUTCOMES OF FHA FIRST-TIME HOMEBUYERS
}

\author{
Donghoon Lee and Joseph Tracy
}

\section{OVERVIEW}

- A key goal of the FHA since its inception has been sustainable homeownership-putting borrowers on the path to owning a home free and clear of debt.

- Noting that the FHA's efficacy in achieving this goal has not been documented, the authors of this study call for a program evaluation, proposing metrics to measure progress toward sustainability.

- The approach employs data from the New York Fed's Consumer Credit Panel, a relatively new source that makes it possible to trace the long-term outcomes for borrowers benefiting from FHA-insured mortgages.

- Sample scorecards provide a range of sustainability measures for first-time borrowers, such as the percentage who pay off their credit risk to the FHA and remain homeowners, who move without a default but return to renting, who remain in their homes still reliant on an FHA mortgage, and who default on their FHA mortgage. he Commissioner of the Federal Housing Administration
(FHA), David Stevens, in a speech delivered on December 12, 2009, defined the purpose of the agency as follows:

As a mission-driven organization, FHA's goal is to provide sustainable homeownership options for qualified borrowers. ${ }^{1}$

These remarks followed a remarkable increase in the scope of the FHA mortgage insurance program in response to the financial crisis and housing bust. Commissioner Stevens' comment is important in that it clarifies a goal of the FHA program. ${ }^{2}$ However, the FHA did not follow up with a definition of "sustainable homeownership." Furthermore, the FHA made no documented attempt to develop metrics to track its progress toward this objective, nor did the FHA commit to making this information available to the public in the future.

Program evaluation is an integral part of any effective program, government or private. We show in this article that advances in data availability offer the FHA an opportunity both to define what it means by sustainable homeownership and to measure its progress against this definition. We believe

\footnotetext{
Donghoon Lee is a research officer at the Federal Reserve Bank of New York. Joseph Tracy is executive vice president and senior advisor to the president of the Federal Reserve Bank of Dallas.Email:donghoon.lee@ny.frb.org; joseph.tracy@dal.frb.org.

The views expressed in this article are those of the authors and do not necessarily reflect the position of the Federal Reserve Bank of New York or the Federal Reserve System.

To view the authors' disclosure statements, visit https://www.newyorkfed.org/research/ epr/2018/epr_2018_first-time-buyers_lee.
} 
that it would be beneficial for the FHA to be transparent in this effort and to report not only its definition and metrics but also on its progress on an annual basis. Improved tracking of the long-term outcomes of FHA borrowers will better help inform the FHA on program design. This effort should lead to improved outcomes over time and enhanced public support.

We focus our analysis on first-time homebuyers, who are an important market segment for the FHA. The goal of sustainable homeownership is particularly relevant for these new homeowners. The benefits of a government mortgage insurance program that helps to facilitate the transition from renting to owning rests importantly on the success of these new borrowers in remaining homeowners in the future. However, to date, the FHA has not systematically tracked the progress of its first-time homebuyers after they pay off their FHA mortgages. To carry out this analysis, we use the New York Fed's Consumer Credit Panel (CCP) data, starting with the 2001 cohort of FHA first-time homebuyers.

\section{A Brief History of FHA Mortgage Insurance}

The Great Depression created a crisis in mortgage finance. During the 1920s, because of state and federal legislation, most mortgages originated by banks were interest-only, with terms between five and ten years. ${ }^{3}$ Banks considered mortgages to be highly illiquid, and therefore, they did not want to commit funds for long terms. ${ }^{4}$ When the loans matured, borrowers would have to either roll over the mortgages or sell their houses. Most states restricted banks and insurance companies from lending more than 50 percent of the appraised value of the house. ${ }^{5}$ This restriction made housing very difficult to purchase. Households either had to save the considerable down-payment amount or take out a second-lien, and possibly even a third-lien, mortgage at high interest rates and initial fees. ${ }^{6}$ Second-lien mortgages tended to have terms of one to three years and required amortization. ${ }^{7}$

This system of mortgage finance was inherently unstable because of the rollover risk facing borrowers. Even for borrowers who managed to acquire the high down payment, additional equity would be required in order to refinance the mortgage if house prices fell. Borrowers who used a second mortgage to help finance the purchase might find access to this financing to be difficult in periods of economic stress. ${ }^{8}$ At the time of the refinancing, borrowers would also be subject to the risk of monthly payment shocks if mortgage rates had increased. Borrowers who had positive equity but who could not roll over their mortgage faced the risk that they would not be able to sell the house in time to avoid default. Potential buyers might themselves find it difficult to attain a mortgage in order to complete the purchase.

These fragilities became clear with the onset of the Great Depression. House prices declined precipitously and unemployment rose sharply. As defaults and foreclosures increased, bank balance sheets came under pressure from the increase in their nonperforming mortgages. A study by the U.S. Department of Commerce in January 1934 estimated that 45 percent of urban owner-occupied homes with mortgages were in default. ${ }^{9}$ In response, the Home Owners' Loan Act of 1933 established the Home Owners Loan Corporation (HOLC) to provide relief to distressed residential mortgage borrowers and their lenders. Over the next three years, HOLC purchased over a million distressed illiquid mortgages from lenders, replacing them with highly liquid government-guaranteed HOLC bonds. ${ }^{10}$ Borrowers, in turn, had their mortgages 
refinanced by HOLC into fifteen-year amortizing mortgages at an LTV of 80 percent with a 5 percent mortgage rate. ${ }^{11}$

HOLC focused on repairing banks' balance sheets rather than those of homeowners. ${ }^{12}$ By statute, HOLC could not offer households a refinanced mortgage for an LTV greater than 80 percent based on a current appraisal. For this reason, the appraisals HOLC used to determine the price at which to purchase distressed mortgages from banks were, on balance, biased upward. Banks were also given the ability to accept or reject HOLC applications on a loan-byloan instead of on a pool basis. Consequently, banks typically were paid face value for most of their distressed mortgages sold to HOLC. This price, in turn, limited the degree to which HOLC could provide principal reductions to borrowers. This approach supported households by encouraging recovery in housing markets so that, over time, debt amortization and house price appreciation would restore borrowers' equity. ${ }^{13}$ Ensuring the ongoing provision of new mortgage credit was viewed as critical to this strategy.

In 1933, however, there was considerable uncertainty over the near-term path of the economy and house prices. In addition, the private mortgage insurance industry that developed at the turn of the century had collapsed. ${ }^{14}$ Without some form of mortgage insurance, banks-even with improved balance sheets as a result of HOLC-would either be reluctant to provide new mortgage credit or would charge a high risk premium that would make new mortgages unaffordable. In addition, the HOLC program had inserted the federal government directly into the business of residential mortgage finance. While this step was viewed as necessary at the time, there was a strong preference to have the private sector quickly resume the lead role in mortgage lending going forward. ${ }^{15}$

The approach taken to support the private-sector provision of mortgage credit was to create a government mortgage insurance program. The National Housing Act of 1934 created the Federal Housing Administration. ${ }^{16}$ The goal for the FHA Section 203(b) mortgage insurance program was to make housing and mortgages more affordable and to mitigate fragilities in mortgage finance. Unlike the earlier private mortgage insurance, which covered only a portion of the borrower's credit risk, the new government mortgage insurance covered all of the credit losses associated with a default. This broader coverage eliminated any need for banks to charge a risk premium even with the considerable economic uncertainty at the time-an important element in keeping mortgages affordable. The FHA insurance required the mortgage to have a 20 percent down payment on a fully amortizing twenty-year fixed-rate mortgage. The maximum loan amount was $\$ 16,000$, but the median house price in 1930 was just $\$ 4,778 .{ }^{17}$ Consequently, the program covered virtually all of the housing market at the time. Borrowers were charged an annual insurance premium of 50 basis points on the amount borrowed. ${ }^{18}$ The FHA-insured mortgages had no prepayment penalty and were assumable. Like the HOLC mortgages, FHA-insured mortgages eliminated rollover risk and facilitated the build-up of equity through amortization in addition to any future house price appreciation. They also eliminated the high fees associated with second mortgages. ${ }^{19}$

At the outset, the FHA government insurance program was designed to support mortgage lending in the private sector. The economy relapsed in 1937, creating additional strains on housing finance. The Steagall National Housing Act of 1938 expanded the FHA's support by reducing the down payment requirement from 20 percent to 10 percent for new homes valued less than $\$ 6,000$. In addition, the loan term was extended from twenty to twenty-five years. Finally, the annual premium was reduced from 50 to 25 basis points. For existing homes, the 
maximum term remained twenty years and the minimum down payment 20 percent. ${ }^{20}$ The guaranteed mortgages represented 23 percent of new lending between 1935 and 1939. The FHA's lending share increased to 45 percent during the war, but then declined to 18.5 percent between 1945 and 1949. ${ }^{21}$

Over the FHA's initial twenty years, the agency's primary focus was on promoting stability in housing markets through providing insurance on mortgages that emphasized the accumulation of borrower equity. This objective was stated in a 1936 publication by the FHA: "The possession of a home, free and clear of all debt at the earliest possible date, should be the goal of every American family."22 That is, sustainable homeownership was a core mission for the FHA at its conception, with the concept of homeownership understood to be a path to owning a home free and clear. Sustainability was supported by a focus on borrower equity, both initially through a down payment and over time through debt amortization. Consequently, by design, these FHA-insured mortgages carried only modest credit risk to the FHA. From 1934 to 1954 , the FHA insured 2.9 million mortgages, and in only 9,253 cases did the borrowers go through a foreclosure-a rate of only 0.3 percent.

The FHA's focus on providing insurance on stable mortgages that emphasized the accumulation of equity diminished over time. As of 1950, with the amendments to the National Housing Act, Section 203, mortgages on existing home mortgages were still subject to the 20 percent minimum down payment and twenty-year maximum term as in the original 1934 legislation. ${ }^{23}$ The current FHA loan term of thirty years was not authorized until 1948 for new construction and 1954 for existing homes. ${ }^{24}$ In a series of legislative changes in the 1950s, minimum down payments were reduced from 12.5 percent for new homes and 20 percent for existing homes under $\$ 10,000$ in 1950 to 3 percent for both types in $1957 .{ }^{25}$ As a consequence of these changes, the amortized LTV on a $\$ 10,000$ home after five years (assuming no house price appreciation) increased from 76.5 percent in 1950 to 91.5 percent in $1961 .{ }^{26}$ Currently, the minimum down payment is 3.5 percent. ${ }^{27}$ In addition, borrowers today can finance their up-front mortgage insurance premium, which further raises the origination LTV and hence borrowers' leverage. The move to a thirty-year term and minimal down payment shifted the FHA's focus over time from sustainable to "affordable" homeownership.

Fisher (1951), writing before the significant liberalization of FHA insurance requirements, commented on the likely futility of trying to maintain affordability in an environment of rising house prices by relaxing underwriting terms:

As prices rise, and it becomes difficult, in spite of the liberalization of mortgage terms, for purchasers to make the required down payments and to carry the necessary monthly payments, a demand ordinarily develops for further lengthening of term and reduction of down payment. Such changes assume, however, that the debt service will be reduced. For it to be so prices would have to remain unchanged. In a buyer's market, they probably would, but apparently not in a seller's. In the latter it is more likely that the liberalization of mortgage terms will increase both the price and the amount of the debt, with debt service remaining approximately unchanged (p. 82).

In a seller's market, further demands for liberalization of lending terms are often made.

A direct consequence was a dramatic increase in default rates on FHA mortgages. We present in Chart 1 Section 203-related foreclosure counts for the period from 1948 to 1961. 
ChART 1

FHA Foreclosure Counts: Section 203

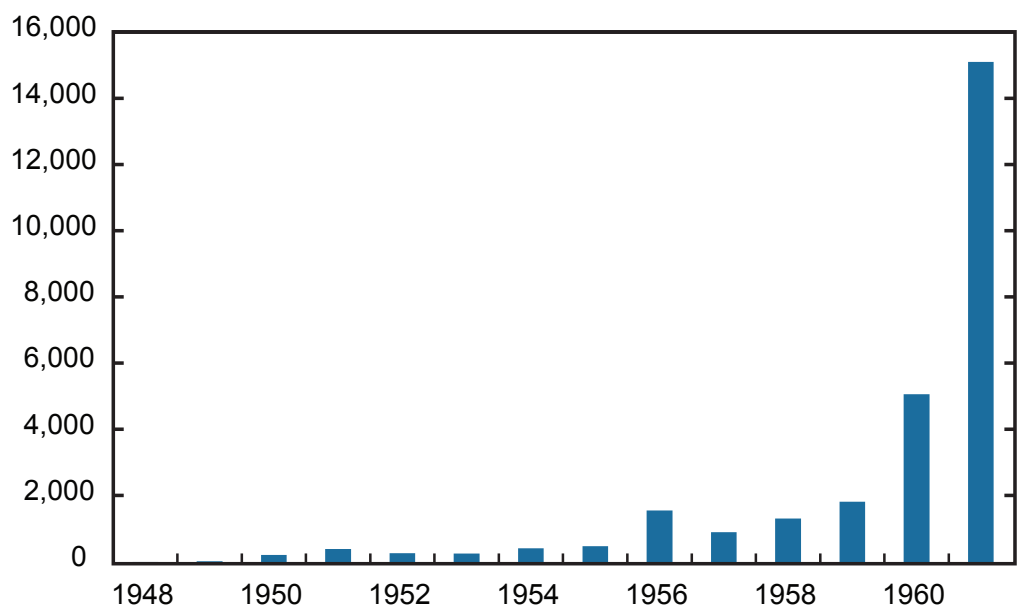

Source: McFarland (1963, Table 2).

Note: FHA is Federal Housing Administration.

In a sample of foreclosures between July 1961 and March 1962, FHA mortgages on existing homes with LTVs between 96 and 97 percent accounted for 49 percent of total foreclosures, yet only 16.8 percent of total insured mortgages. ${ }^{28}$ This connection between the increase in foreclosures and the easing of FHA underwriting standards was identified in the FHA's 1963 report, which explained:

There can be no question that the assumption by FHA of progressively increasing risks to accomplish the legislative objective of making home purchases more widely possible has had an influence on the recent FHA property acquisition experience. ${ }^{29}$

From 1977 to 2013, the average FHA default rate had increased to 12 percent-forty times higher than the rate over its first twenty years. ${ }^{30}$

This default rate is inconsistent with claims that the FHA has remained focused on sustainability. Going forward, if the FHA maintains the goal of sustainable homeownership, it would be helpful for the FHA to take accountability for the goal and produce a scorecard on its performance relative to it.

\section{Measuring the Sustainability of Homeownership}

What factors would one look at in defining and measuring the sustainability of homeownership for first-time buyers? A clear case where sustainability is not met is when the borrower defaults and loses the house, damaging his or her credit rating. Conditional on a default, it 
will take years for the borrower to repair his or her credit and potentially transition back to homeownership. ${ }^{31}$ To date, the FHA has not clarified what default rate it views as compatible with the goal of sustainable homeownership. Such clarification would be an important first step.

As discussed in Caplin, Cororaton, and Tracy (2015), in the case of the FHA, default should be measured at the borrower and not the mortgage level. The FHA has an internal refinancing program that allows borrowers with FHA-insured mortgages to refinance even if they are in negative equity. In fact, borrowers can refinance multiple times. This program is a sensible one given that the FHA already has the credit exposure to the borrower and a lower mortgage rate will reduce the likelihood of a default. ${ }^{32}$ During the housing bust and the Great Recession, this internal refinancing activity was quite prevalent. As a result, if we followed a FHA first-time purchase mortgage and observed that it was paid off in full, this payoff could be associated with an internal refinancing, and not a sale of the house and a paying down of the FHA's credit exposure related to the household. In addition, the refinanced mortgage that replaces the original purchase mortgage could subsequently end in default. Consequently, we need to follow the borrower through any FHA-refinanced mortgages connected to the purchase mortgage to determine whether the borrower defaulted or successfully paid off the credit risk to the FHA. Previously, this was a difficult empirical exercise for outside researchers, but it could easily be done using internal FHA data. As we will discuss, new data allow us to compute FHA default rates at the borrower level.

On the other end of the spectrum, those first-time borrowers who sustain their homeownership by remaining homeowners consist of both those households that move and those that don't move. For the households that move and remain homeowners, we can divide them into those that no longer rely on an FHA-insured mortgage and those that still have an FHA-insured mortgage. Similarly, for those households that did not move, we can divide them into those that refinanced to a non-FHA-insured mortgage and those that still have an FHA-insured mortgage. ${ }^{33}$ For both the movers and the stayers who remain homeowners, we may want to count as more successful those households that have "graduated" out of the FHA system. For the movers, we want to allow for the possibility that a household may rent for a brief transition period between homeownership experiences. The length of this period needs to be selected so that if the household is not observed owning a home during this period, we are comfortable treating this as a real break in the homeownership experience.

In this partition of FHA first-time homebuyers, the remaining group consists of those households that pay off their credit risk to the FHA without defaulting, but that do not transition to a new homeownership experience during the allowed period of time. That is, these are households that are observed to be continuously renting for the full time period selected following the pay off on their credit risk to the FHA. Like defaulters, this group did not sustain their homeownership. However, the costs of their failure to do so are much less than for the group of defaulters.

Implementing this partition of the long-term outcomes of FHA first-time homebuyers involves considerable demands. Initially, we need to be able to distinguish FHA first-time purchase mortgages from trade-up FHA purchase mortgages. The FHA classifies a purchase mortgage as a first-time mortgage if the borrower has not had a mortgage in at least three years. A cleaner identification would look to see that there are no mortgage liens in a borrower's full credit history. 
Having identified the set of FHA first-time homebuyers, we need data that allow us to track these households over time and observe any subsequent mortgage liens and the locations of the properties that secure them. ${ }^{34}$ This combination allows us to properly measure FHA default rates for first-time homebuyers. In addition, the availability of subsequent mortgage lien and location information allow us to classify those households that transition to new homeownership experiences and those that transition to renting. Loan-level mortgage servicing data will not meet these data requirements.

\section{The New York Fed’s Consumer Credit Panel}

Here we describe the approach for producing a sample scorecard on the sustainability of FHA first-time homebuyers. The New York Fed's Consumer Credit Panel (CCP) consists of Equifax credit-report data for a 5 percent random sample of U.S. households. ${ }^{35}$ Since it is a longitudinal panel, we can follow the credit files of the household members over time. The quarterly data begin in 1999. In addition to a detailed summary of the households' credit at each point in time, the data have scrambled mailing addresses for the household along with zip codes and county information. Narrative codes are provided, and these codes allow us to identify mortgage liens as FHA, Veterans Affairs (VA), government-sponsored entity (GSE) securitized, and "other" (privately securitized and bank portfolio). ${ }^{36}$ For each mortgage, the CCP provides the current balance and the payment status as of the end of that quarter.

The CCP satisfies the data requirements for our sustainability scorecard. We create a cleaner identification of FHA first-time homebuyers than the official FHA measure because we are able to look at the entire history of the households' credit files back to 1999 in conjunction with the information indicating the age of the oldest mortgage, including open and closed mortgages, on the credit report. We define a first-time mortgage as the first appearance of an active mortgage since 1999 and no trace of any prior closed mortgages on the borrower's credit report. We start our analysis with the 2001 cohort of first-time homebuyers. This gives us a much longer window than the FHA's definition using a three-year window. ${ }^{37}$

By observing the mortgage balance and location of the household, we can identify internal FHA refinances. This detail allows us to follow a household from its FHA first-time purchase mortgage through any subsequent FHA refinances to the final disposition of the FHA credit exposure on that property. If any subsequent internally refinanced mortgage goes into default, we link that default back to the original purchase mortgage.

The CCP data also allow us to determine whether a household continues homeownership following the payoff of its first FHA credit exposure. We can identify whether the household changes address, remains in the same zip code, or moves to a new zip code, and whether it acquires a new mortgage lien. We interpret the absence of any mortgage lien associated with a different address as evidence that the household is renting. ${ }^{38}$ 


\section{CHART 2}

Purchase Mortgage Originations: First-Time and Repeat

First $\square$ Repeat

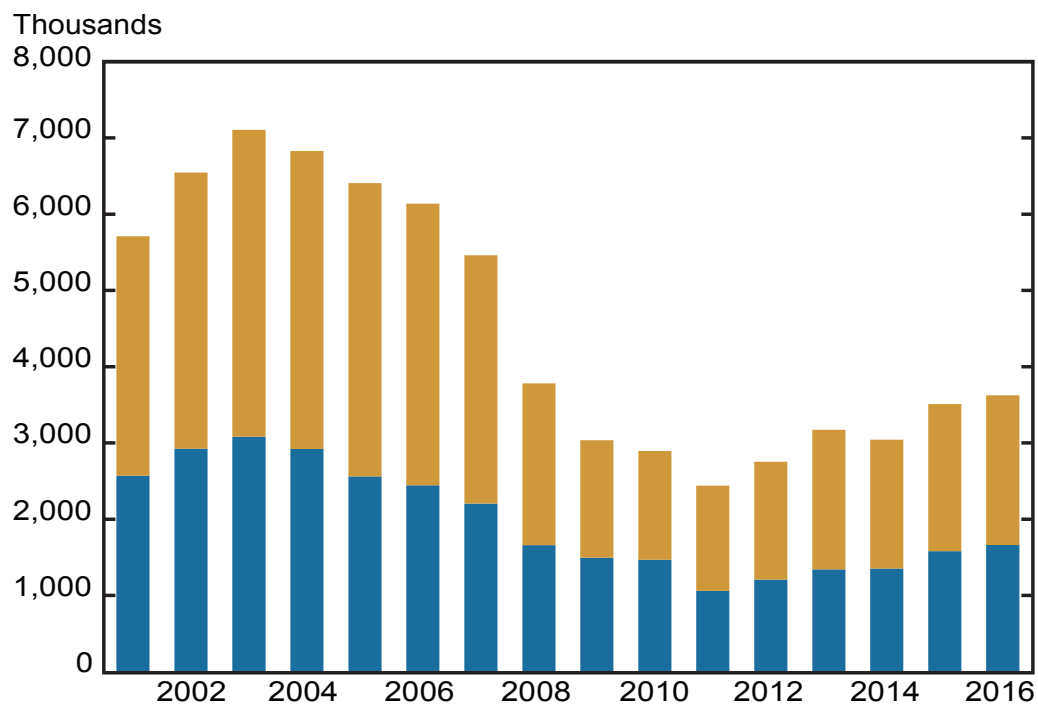

Sources: New York Fed Consumer Credit Panel/Equifax data; authors' calculations.

\subsection{FHA First-Time Homebuyers}

\section{Dimensions of the first-time market}

We turn now to using the CCP data to provide some description that is informative about first-time homebuyers in general and FHA first-time homebuyers in particular. Chart 2 shows the flow by year of purchase mortgages broken down between first-time and repeat status. The flow of purchase mortgages peaked in 2003 at 7.1 million. ${ }^{39}$ The pace of new purchase mortgages then declined, reaching a trough in 2011 at 2.4 million-a third of its prior peak. Purchase mortgage originations since 2011 have slowly recovered, reaching 3.6 million in 2016.

In 2002, first-time mortgages comprised 45 percent of overall purchase mortgages. As the housing boom intensified, the first-time share declined modestly, to 40 percent. From 2008 to 2010, with the onset of steep house-price declines associated with the housing bust, the first-time share increased, reaching 51 percent in 2010. Over the next three years, the first-time share again dropped, falling back to 42 percent in 2013. Since then, the first-time share has recovered somewhat and held steady at around 45 to 46 percent. ${ }^{40}$ Appendix 1 provides a quarterly time-series on the first-time purchase mortgage share from 2002 to 2016 using both our definition and the traditional three-year look-back definition. We see that using the three-year look-back to define first-time buyers consistently overstates the first-time share by 10 percentage points or more.

Chart 3 shows the flow of first-time purchase mortgages by year disaggregated by FHA, VA, GSE, and other. From 2001 to 2006, the volume of GSE first-time mortgages fluctuated from 


\section{CHART 3}

First-Time Purchase Mortgage Originations: By Type

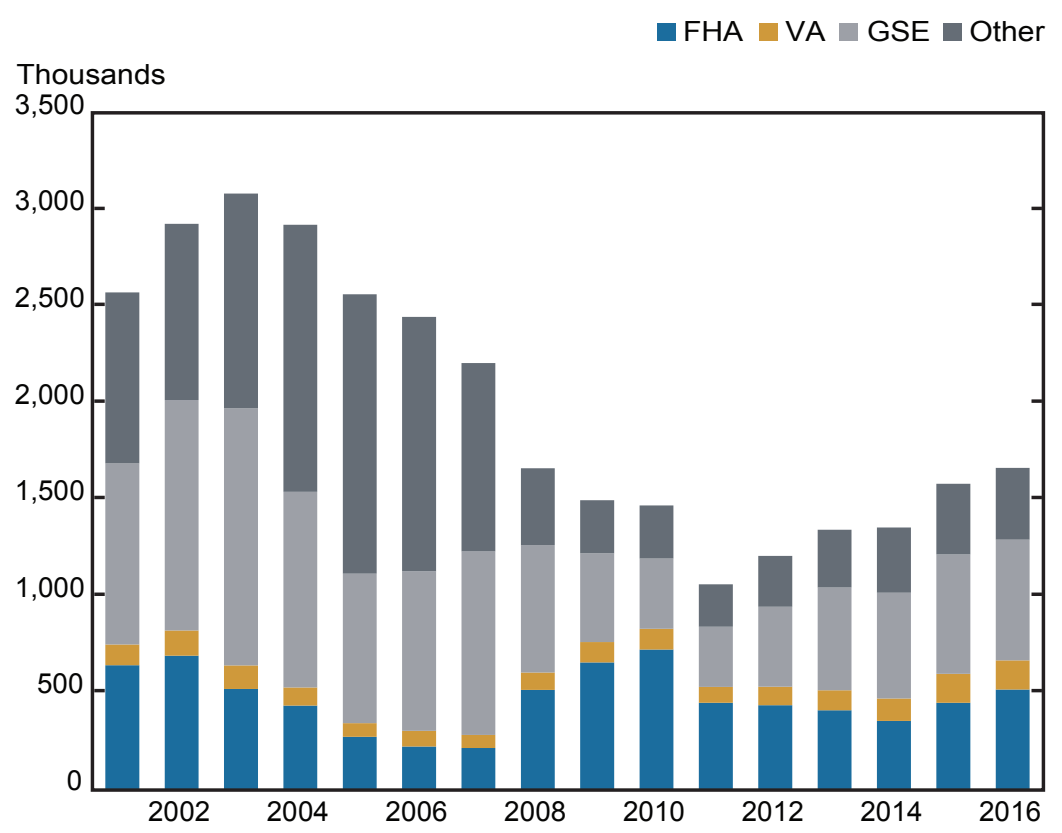

Sources: New York Fed Consumer Credit Panel/Equifax data; authors' calculations.

Note: FHA is Federal Housing Administration, VA is Veterans Affairs, and GSE is government-sponsored enterprise; "other" are privately securitized and bank portfolio mortgages.

1.5 to 3.8 times the volume of FHA first-time mortgages. The overall flow of first-time purchase mortgages peaks in 2003 at around 3.2 million loans. In the early 2000s, both the FHA and GSE market shares of first-time mortgages were being competed away by the private-label security market. This compression of the FHA and GSE shares continued until 2006 and then started to reverse in 2007 as the private-label security market began to implode. By 2008, as the financial crisis intensified, FHA first-time originations began to grow dramatically and eclipsed GSE originations from 2009 to 2012. The GSE market share began to recover slowly beginning in 2012.

We show in Chart 4 the share of FHA first-time purchase mortgages relative to all FHA purchase mortgages by year. First-time buyers have traditionally been a very important constituent for the FHA. In the early to mid-2000s, first-time mortgages represented from 73 to 77 percent of all FHA purchase mortgage originations. The first-time share for the VA program was close behind at between 56 and 61 percent during this period. In contrast, the first-time shares for the GSEs and other programs were much lower, at around 39 percent. With the onset of the financial crisis, the FHA's first-time share dropped to 66 percent in 2008 and continued to trend downward, reaching 58 percent in 2015. The FHA's first-time share rebounded in 2016, to 62 percent.

The credit profile of FHA first-time buyers over time is shown in Chart 5. From 2001 to 2007, borrowers with credit scores below 640 represented around half of the flow of new FHA 


\section{Chart 4}

FHA First-Time Purchase and Repeat Mortgage Originations

First $\square$ Repeat

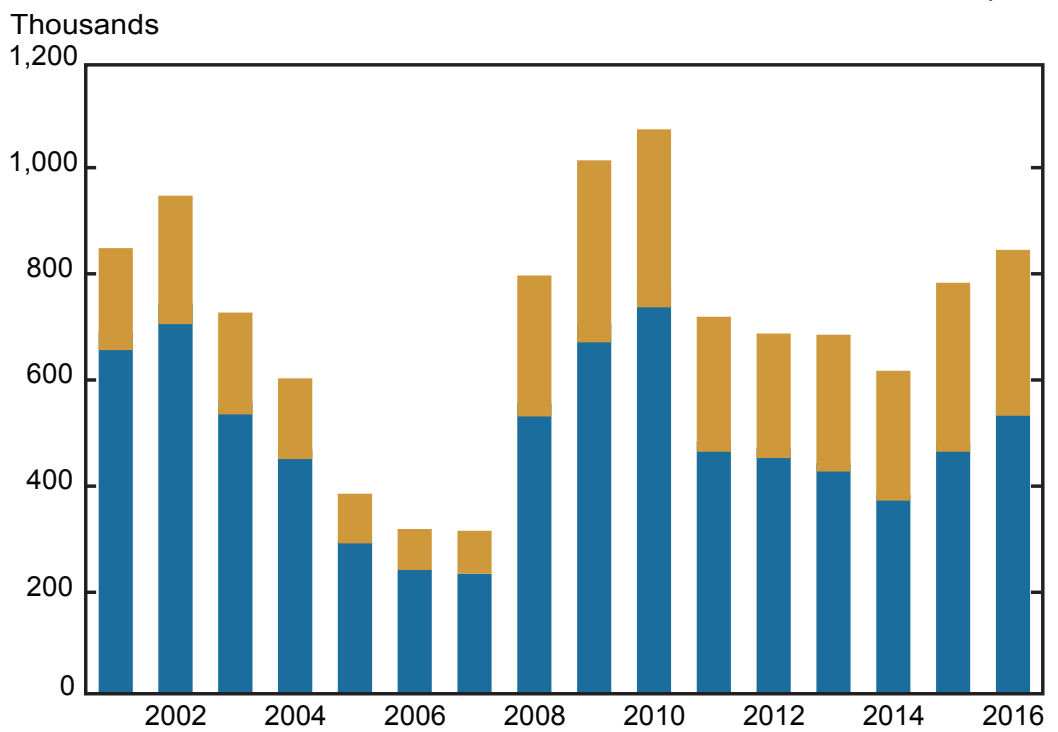

Sources: New York Fed Consumer Credit Panel/Equifax data; authors' calculations.

\section{Chart 5}

Credit Score Distribution for FHA First-Time Buyers

- Below $560 \square$-560-599 600-639

-640-679 680-719 720-759 760 plus

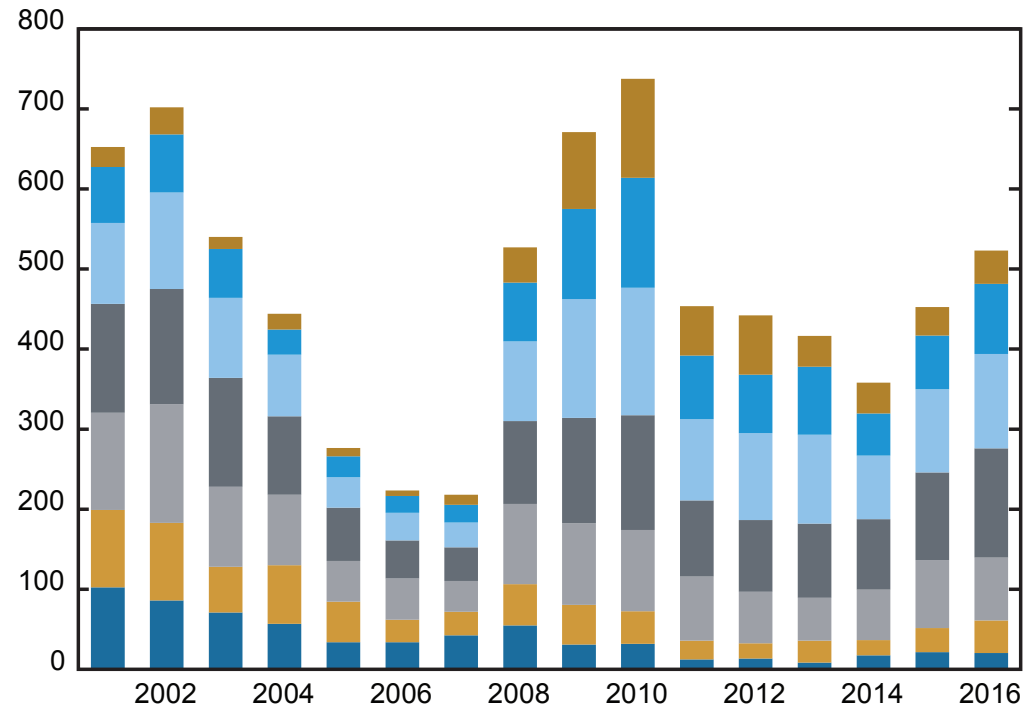

Sources: New York Fed Consumer Credit Panel/Equifax data; authors' calculations.

Note: The buyer's credit score equals the Equifax risk score. 
CHART 6

Credit Score Distribution for VA First-Time Buyers
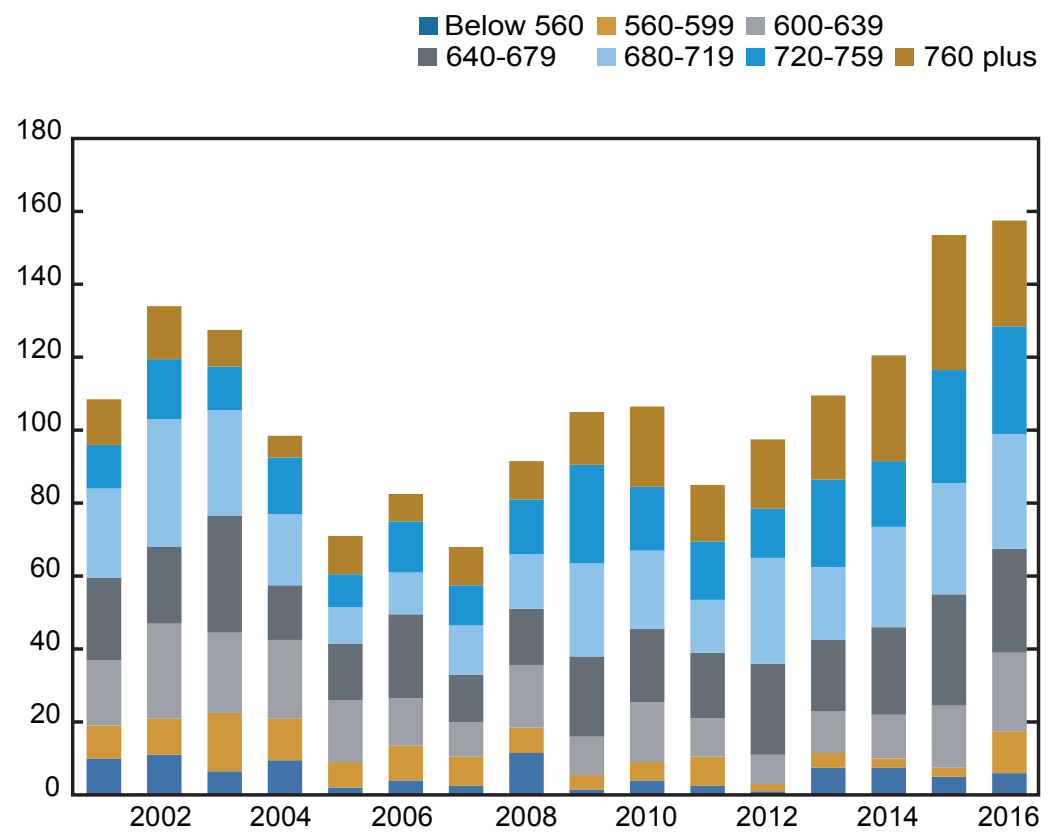

Sources: New York Fed Counsumer Credit Panel/Equifax data; authors' calculations.

Notes: VA is Veterans Affairs. The buyer's credit score equals the Equifax risk score.

first-time buyers. As the FHA's role in the first-time market expanded in 2008, it began to attract higher-credit borrowers. The share of FHA first-time buyers with credit scores below 640 declined to roughly a third of its flow in 2008 and 2009 and remained around a quarter in the 2010 to 2016 period. In comparison, the credit profile of VA first-time buyers is relatively better than those with FHA mortgages, as shown in Chart 6. The share of VA first-time buyers with credit scores below 640 was around 35 percent from 2001 to 2007 and declined to about 20 percent from 2010 to 2016.

\section{An FHA first-time buyer sustainability scorecard}

With this background, we now turn to describing how the FHA has performed on its mission of sustainable homeownership for its first-time buyers. Chart 7 shows the five categories of outcomes discussed earlier for the 2001 to 2010 cohorts. The focus of our discussion is on the 2001 and 2002 cohorts of FHA first-time buyers for two reasons: we have the longest history to track their sustainability, and they were less affected by the financial crisis relative to later cohorts. Starting with the most obvious example of a failure of sustainability, roughly 12 percent of the 2001 and 2002 FHA first-time buyers saw their homeownership experience end in default. ${ }^{41}$ The default rates increased for later cohorts, reaching a peak of 30 percent for the 2006 cohort of FHA first-time buyers. 
CHART 7

FHA First-Time Buyers Sustainability Scorecard

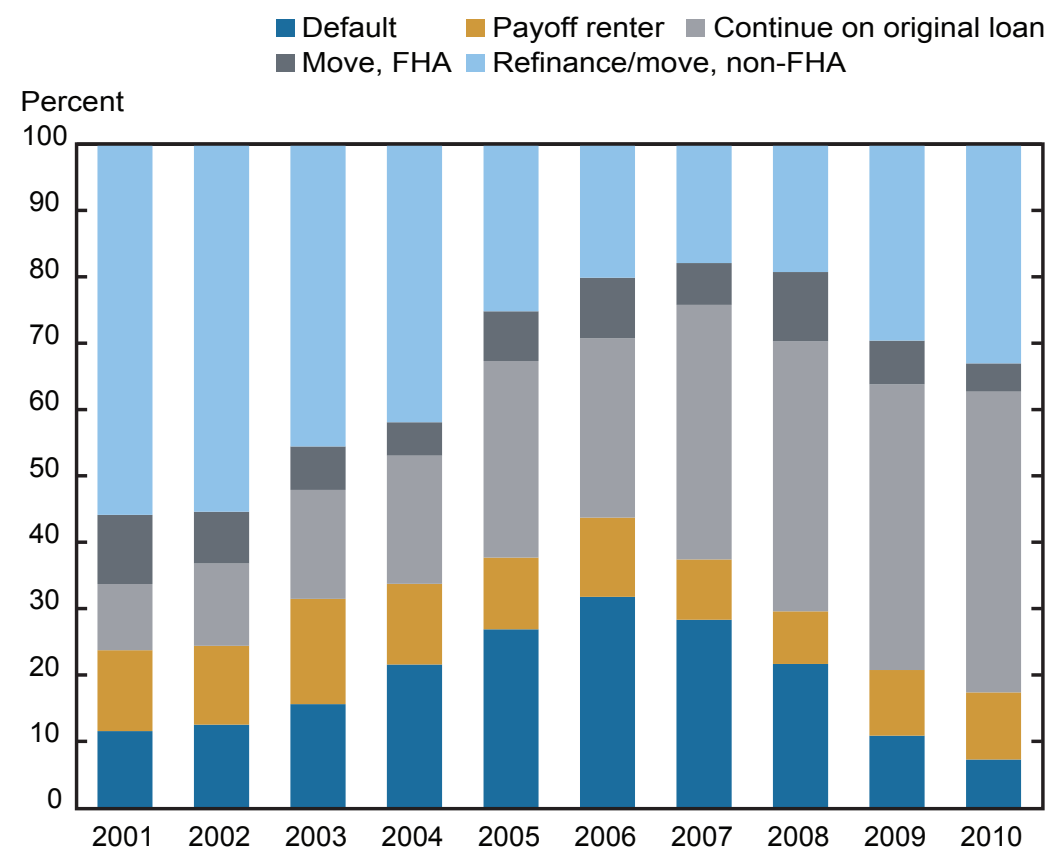

Sources: New York Fed Consumer Credit Panel/Equifax data; authors' calculations.

Note: FHA is Federal Housing Administration.

The second category representing a failure of sustainability of homeownership consists of those first-time buyers who are able to pay off their FHA mortgages, but who transition back to renting. Again, we use a three-year window after the payoff of the FHA mortgage for a household to transition back to homeownership. The data indicate that 12 percent of these two cohorts of FHA first-time buyers transitioned back to renting after paying off their FHA mortgage. While these buyers did not incur the costs of default, they did not sustain their homeownership. Combining the two, between 24 percent of these two vintages of FHA first-time buyers did not sustain their homeownership.

The most compelling category of sustainable homeownership consists of those households that pay off their FHA first-time mortgage, move, and remain homeowners without the need for a subsequent FHA mortgage. ${ }^{42}$ These households graduate out of the FHA system while remaining homeowners. ${ }^{43}$ For the 2001-02 cohorts, 55 percent met this criterion.

The final two categories fall in the middle between clear success and failure to sustain homeownership. The first are those households that remain in the same home, continuing to pay off their FHA first-time mortgage (or subsequently refinance). For the 2001-02 cohorts, these households have been homeowners continuously for fourteen to fifteen years. Consequently, they are building up equity in their homes and have experienced sustained homeownership. However, what we do not know is whether some of these families desired to move, but 
CHART 8

VA First-Time Buyers Sustainability Scorecard

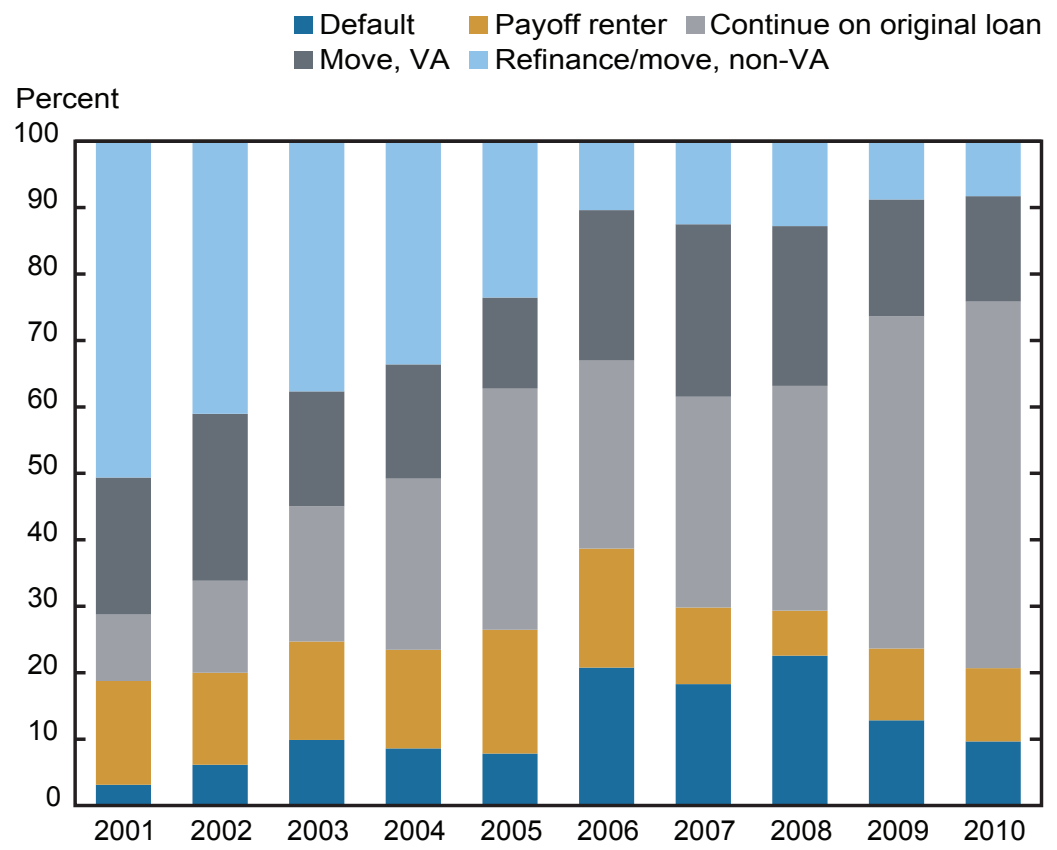

Sources: New York Fed Consumer Credit Panel/Equifax data; authors' calculations.

Note: VA is Veterans Affairs.

remained perhaps in part because of a financial friction associated with their FHA mortgages. ${ }^{44}$ This category represents about 10 to 12 percent of these two cohorts of FHA first-time buyers.

The second of these two groups with less clear outcomes is the one whose households pay off their FHA first-time mortgage and purchase a trade-up home. However, they finance this trade-up purchase with an FHA mortgage. That is, they do not graduate from the FHA system. Again, these households are able to sustain their homeownership and to move. In this sense, they are a success. A goal of the FHA may be, though, to allow more households to be able manage this transition without needing an FHA mortgage. Roughly 8 to 10 percent of the 2001-02 cohorts fell into this category.

As we have demonstrated, the CCP data allow us to develop a scorecard for FHA sustainable homeownership. Focusing on the 2001 and 2002 cohorts, the data indicate that 55 percent of first-time buyers sustained homeownership, using the most conservative definition. Using a less conservative definition of sustainability, the data indicate that 80 percent of FHA first-time buyers in these two cohorts sustained their homeownership experience.

In Chart 8 (above), we provide for comparison a similar scorecard for VA first-time buyers. We use the same categories as we did for the FHA program. The default rates for the 2001 and 2002 VA first-time cohorts were from 3 to 6 percent-at most, half the default rates for the same FHA cohorts. A higher fraction of these VA cohorts, though, transition to renting after paying off their VA mortgage. Consequently, around 20 percent of households in these 
two VA cohorts fail to sustain their homeownership experience. While this is slightly lower than the percentage of FHA first-time buyers who either default or return to renting, the two programs differ more in terms of the mix between defaulters and nondefaulting renters.

In terms of clear cases of sustainability, 41 to 51 percent of the 2001-02 VA cohorts pay off their VA mortgages, move, and remain homeowners without relying on a subsequent VA mortgage - a lower percentage than for the FHA program. When we add in those households that move but rely on a VA mortgage for their trade-up purchase, the FHA and VA programs have similar sustainability results for these two cohorts. Appendix 2 provides a sustainability analysis for GSE and other first-time buyers.

\section{Conclusion}

A stated mission of the FHA mortgage insurance program is to support sustainable homeownership. An examination of the history of the FHA program illustrates a strong initial focus on sustainability, but changes legislated in the 1950s and early 1960s shifted the focus to affordability. If sustainability remains an important goal for the FHA, it would be desirable for the FHA to define what it means by sustainability and to track its performance over time. Only by being transparent and holding itself accountable can the FHA improve on this objective over time.

In this article, we have demonstrated that data are now available to track a variety of measures of sustainability. This example demonstrates the feasibility of the FHA developing a sustainability scorecard. Our objective was neither to argue for any particular definition of sustainability, nor to define numerical goals for any specific measure. Rather, we sought to illustrate that there are no data-related obstacles prohibiting the FHA from undertaking this analysis and reporting on its findings. By doing so, the FHA can better run its program and thus maintain a case for taxpayer support. 


\section{Appendix 1}

The FHA classifies a purchase mortgage as a first-time mortgage if the borrower has not had a mortgage in at least three years. A cleaner identification, using the Consumer Credit Panel data, would establish that there are no mortgage liens in a borrower's full credit history. The chart below provides a quarterly time-series on the first-time purchase mortgage share from 2002 to 2016. We see that using a three-year look-back versus a review of full credit histories consistently overstates the first-time share by 10 percentage points or more.

\section{First-Time Purchase Mortgage Share}

First-time share (within three years)

First-time share (ever)

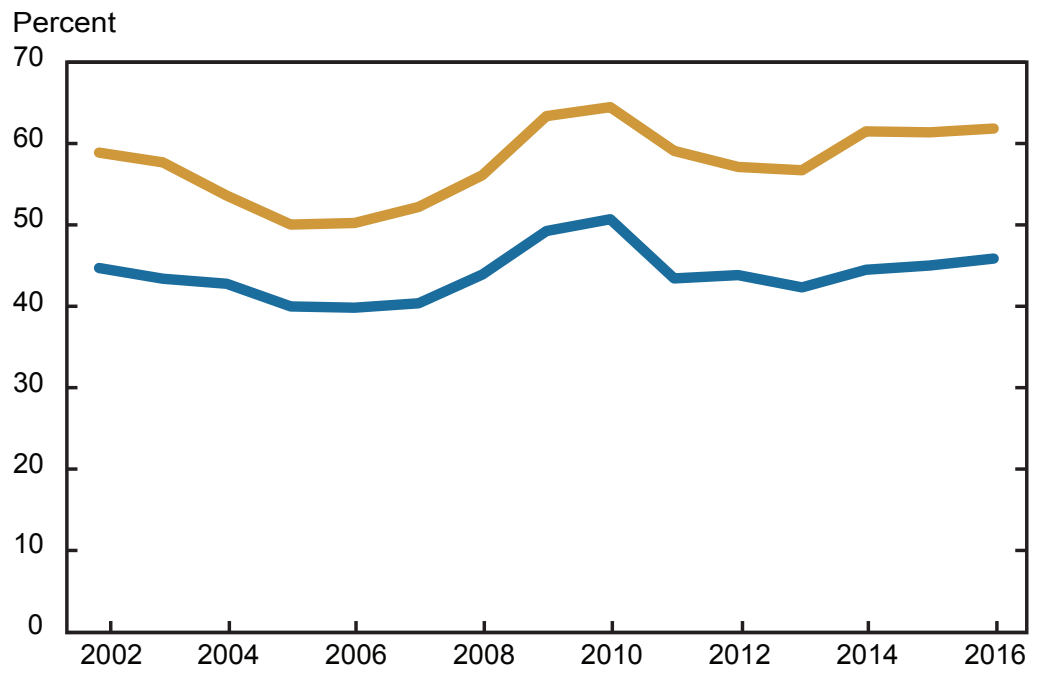

Sources: New York Fed Consumer Credit Panel/Equifax data; authors' calculations. 


\section{ApPENDIX 2}

For completeness, in Charts $2 \mathrm{~A}$ and $2 \mathrm{~B}$, we provide sustainability scorecards for the remaining two first-time mortgage categories: GSE and other. In each of these cases, there is no reason to distinguish between movers who purchase a trade-up house using a similar type of mortgage. However, for comparability, we break out these two categories as before.

Chart 2A

GSE First-Time Buyer Sustainability Scorecard

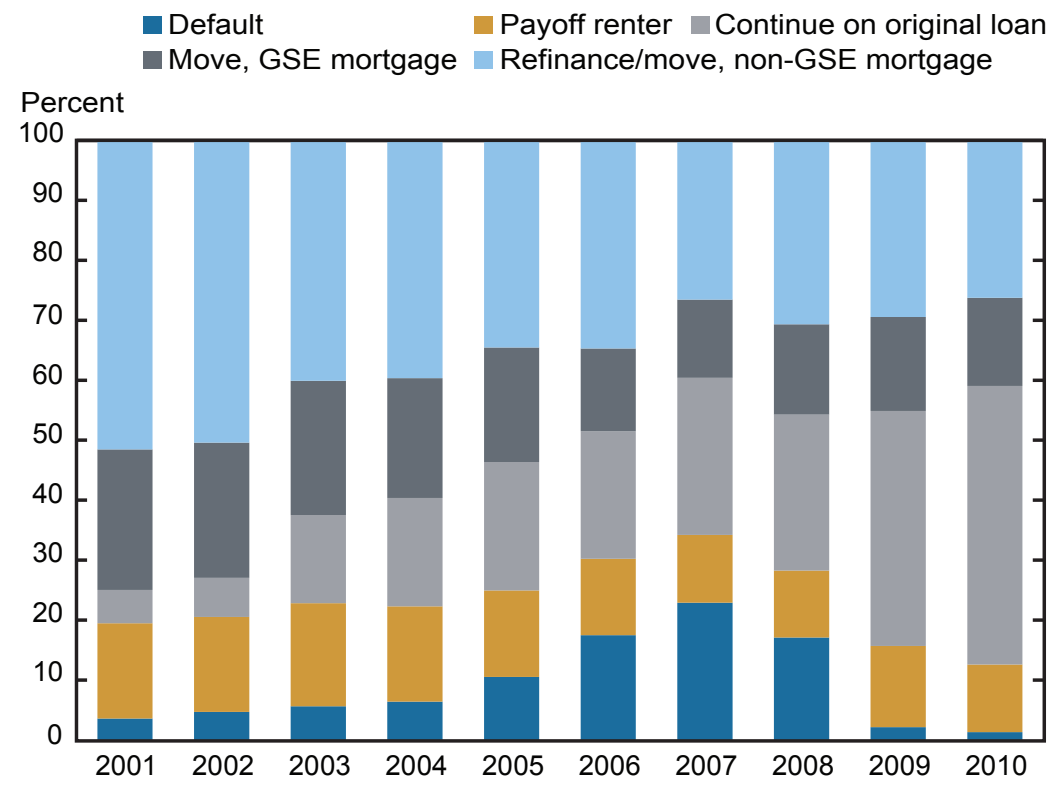

Sources: New York Fed Consumer Credit Panel/Equifax data; authors' calculations.

Note: GSE is government-sponsored enterprise. 


\section{Appendix 2 (Continued)}

\section{Chart 2B}

Other First-Time Buyer Sustainability Scorecard

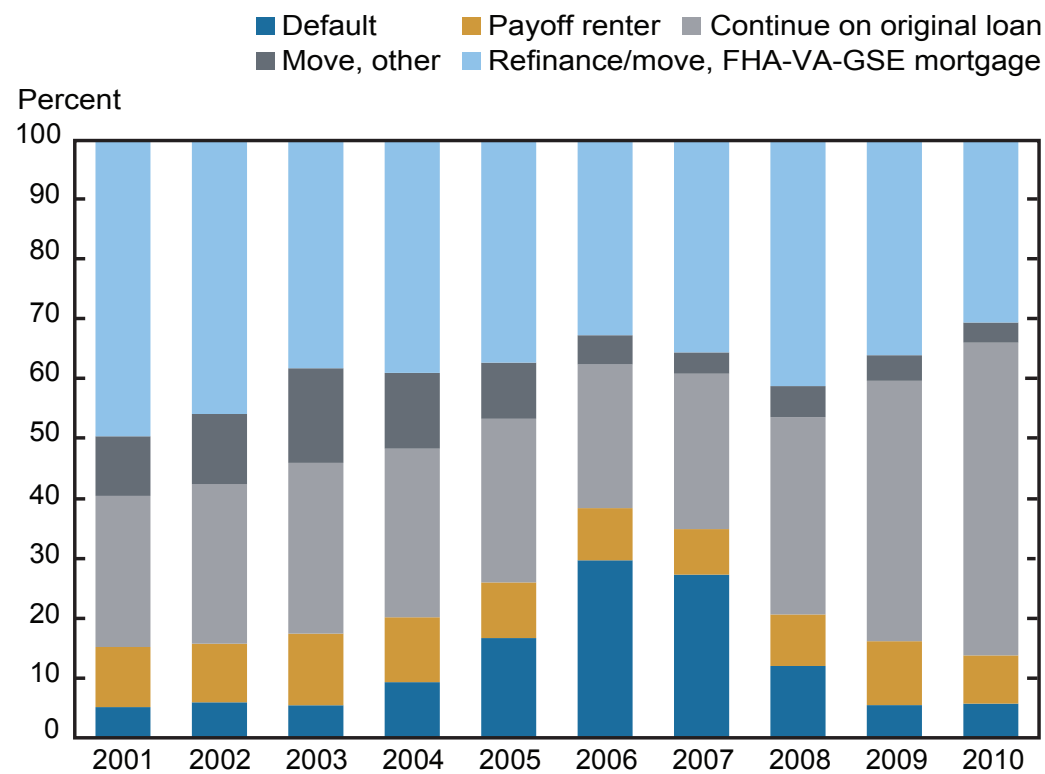

Sources: New York Fed Consumer Credit Panel/Equifax data; authors' calculations.

Note: FHA is Federal Housing Administration, VA is Veterans Affairs, and GSE is government-sponsored enterprise; "other" are privately securitized and bank portfolio mortgages. 


\section{Notes}

Acknowledgments: The authors thank Scott Frame, Ed Pinto, and Susan Wachter for helpful discussions and background material.

1 "FHA Commissioner David Stevens Addresses Mortgage Industry Policy Concerns," National Mortgage Professional, December 18, 2009.

${ }^{2}$ The FHA, in its 2015 Annual Management Report, reiterated this mission as follows: "Today, FHA continues to serve the nation by stabilizing the housing market; ... [and] promoting sound, sustainable and affordable housing."

${ }^{3}$ The National Bank Act of 1864 prohibited national banks from holding mortgages with terms greater than five years. See Gries and Ford $(1932, \mathrm{x})$. In contrast, the average term for mortgages from building and loan associations (and mutual savings banks in the Northeast) tended to vary from seven to twelve years. Building and loan associations and life insurance companies generally originated amortizing mortgages. Mutual savings banks and insurance companies were moving toward amortized mortgages. Gries and Ford (1932, 20, 26). See also Lloyd (1994).

${ }^{4}$ See Gries and Curran $(1928,5)$.

${ }^{5}$ See Herzog (2009).

${ }^{6}$ Origination fees for second mortgages typically were 15 to 20 percent of the loan balance. See Gries and Ford $(1932,28)$. These high fees were a means of avoiding usury laws that applied to interest rates. See Gries and Curran $(1928,10)$. The seller of the property often holds the third mortgage if one exists, Gries and Curran $(1928,11)$.

${ }^{7}$ Second liens reduced the down payment in many cases to less than 10 percent. See Gries and Ford $(1932,20-21,29)$.

${ }^{8}$ Many second mortgage companies failed during the Depression. Those that survived tended not to lend beyond a cumulative loan-to-value ratio (LTV) of 75 percent. See Gries and Ford (1932, 10, 29-30).

${ }^{9}$ See Wheelock (2008).

${ }^{10} \mathrm{HOLC}$ received applications for 1,886,491 refinances, of which 1,017,948 were approved, an approval rate of 54 percent. See Fisher (1951).

${ }^{11}$ Forbearance of principal payments was also allowed for up to three years. It took until 1951 to wind down the HOLC loan portfolio.

${ }^{12}$ For more details, see Rose (2011).

${ }^{13}$ After seven years, amortization would produce an updated LTV of 50 percent, assuming no change in house values.

${ }^{14}$ See Alger (1934).

${ }^{15}$ See Herzog $(2009,18)$.

${ }^{16}$ Title II, section 203(b).

${ }^{17}$ See Vandell $(1995,302)$.

${ }^{18}$ This annual fee was unchanged until 1983 when it was replaced with an up-front premium of 3.8 percent that could be financed into the balance of the mortgage. In 1990, the 0.5 percent annual fee was reinstated for a specific duration depending on the LTV. See Vandell $(1995,332)$.

${ }^{19}$ FHA representatives had to meet with each state legislature in order to amend state restrictions against lending institutions holding the types of mortgages to be guaranteed by the FHA. See Lloyd $(1994,65)$.

${ }^{20}$ See Fisher (1951).

${ }^{21}$ See Vandell $(1995,307)$.

${ }^{22}$ Federal Housing Administration (1936). 


\section{Notes (Continued)}

${ }^{23}$ Section 203 refers to the main FHA insurance program. See McFarland $(1963,22)$.

${ }^{24}$ See Pinto (2015).

${ }^{25}$ This reflected legislative changes in 1954, 1956, 1957, 1958, 1959, and 1961. See McFarland (1963, Table 7).

${ }^{26}$ The ten-year amortized LTV increased from 63 percent in 1950 to 84.3 percent in 1961. See McFarland (1963, Table 8).

${ }^{27}$ This minimum applies to borrowers with a credit score of 580 or higher.

${ }^{28}$ In contrast, mortgages with LTVs of 80 percent or less accounted for only 1.2 percent of all foreclosures and 12.4 percent of total insured mortgages. McFarland (1963, Table 12).

${ }^{29}$ Foreclosures in the early 1950s were also subdued because of rapid house price appreciation.

${ }^{30}$ See Pinto (2015). Also, see Vandell (1995) for a discussion of the FHA and broader housing policy from the 1970s to the early 2000s.

${ }^{31}$ See Brevoort and Cooper (2010).

${ }^{32}$ See, for example, Tracy and Wright (2016) and Fuster and Willen (2017).

${ }^{33}$ For well-seasoned vintages, a household that is still in its original FHA purchase mortgage (or a subsequent internal refinance) has demonstrated sustainable homeownership. For newer, unseasoned vintages, many of these households will likely move into one of our other outcome categories as time goes by.

${ }^{34}$ In the CCP data, the location information is the mailing address for the borrower.

${ }^{35}$ See Lee and van der Klaauw (2010).

${ }^{36}$ The GSE mortgages originated by some lenders were not coded as such, and we classified them as "other." Consequently, the GSE category is an undercount of the GSE population.

${ }^{37}$ This definition was introduced in the Federal Housing Enterprises Financial Safety and Soundness Act of 1992. Beginning that year, the Uniform Residential Loan Application collected this information in Section VIII $\mathrm{m}$.

${ }^{38}$ Note that we would misclassify situations where a household inherits a parent's house and moves in without a mortgage, or inherits enough wealth to be able to pay cash for a house.

${ }^{39}$ Note that the peak in purchase mortgage originations was three years prior to the peak in house prices.

${ }^{40}$ Oliner and Pinto (2016) report a first-time share of 52.1 percent in March 2016, up from 51.4 percent in March 2015 based on data that define a first-time buyer using a three-year look-back period. The CCP data indicate lower first-time shares of 44 percent in the first quarter of 2016 and 43 percent in the first quarter of 2015 . When we restrict our definition of first-time buyer to only the three-year look-back period, we get shares of around 61 to 62 percent for these two time periods-higher than the Oliner and Pinto estimates.

${ }^{41}$ Default is defined as terminating the loan history with " $120+$ days past due" or "charged off."

${ }^{42}$ The combination of moving and remaining homeowners implies that these households purchased a trade-up home and financed it with a non-FHA mortgage.

${ }^{43}$ Vandell $(1995,332)$ points out that, in the early 1990s, the "unused" portion of the FHA insurance premium could be refunded to borrowers who refinanced into a conventional mortgage instead of another FHA mortgage. This suggests that the FHA had an interest in first-time borrowers graduating from the FHA mortgage guarantee program.

${ }^{44}$ FHA mortgages are assumable but not portable. The assumable feature should mitigate financial frictions. 


\section{REFERENCES}

Alger, G.W. 1934. Report to His Excellency Herbert H. Lehman, Governor of New York, Moreland Commissioner's Report, October 5.

Brevoort, K. P., and C. R. Cooper. 2010. "Foreclosure's Wake: The Credit Experience of Individuals Following Foreclosure." Board of Governors of the Federal Reserve System Finance and Economics Discussion Series, no. 3010-59, November.

Caplin, A., A. Cororaton, and J. Tracy. 2015. "Is the FHA Creating Sustainable Homeownership?" Real Estate Economics 43, no. 4: 957-92.

Federal Housing Administration. 1936. "How to Have the Home You Want."

—2015. Annual Management Report.

Fisher, E. M. 1951. "Financing Home Ownership." In E.M. Fisher, ed., Urban Real Estate Markets: Characteristics and Financing. New York: National Bureau of Economic Research.

Fuster, A., and P. Willen. 2017. "Payment Size, Negative Equity, and Mortgage Default." American Economic Journal: Economic Policy 9, no. 4 (November): 167-91.

Gries, J. M., and T. M. Curran. 1928. "Present Home Financing Methods.” U.S. Department of Commerce, Division of Building and Housing.

Gries, J. M., and J. Ford, eds. 1932. Home Finance and Taxation. Reports of the Committees on Finance and Taxation. Washington, D.C.: President's Conference on Home Building and Home Ownership.

Herzog, T. N. 2009. "History of Mortgage Finance with an Emphasis on Mortgage Insurance." Society of Actuaries.

Lee, D., and W. van der Klaauw. 2010. "An Introduction to the FRBNY Consumer Credit Panel." Federal Reserve Bank of New York Staff Reports, no. 479, November.

Lloyd, R. E. 1994. "Government-Induced Market Failure: A Note on the Origins of FHA Mortgage Insurance.” Critical Review 8, no. 1 (winter): 61-71.

McFarland, M. C. 1963. "FHA Experience with Mortgage Foreclosures and Property Acquisitions." A Report of the Federal Housing Administration.

Oliner, S. D., and E. J. Pinto. 2016. "March First-Time Buyer Update from AEI’s ICHR." AEIdeas blog, April 18. 


\section{REFERENCES (CONTINUED)}

Pinto, E. J. 2015. "Housing Finance: Fact or Fiction? FHA Pioneered the Thirty-Year Fixed Rate Mortgage during the Great Depression?” AEIdeas blog, June 24.

Rose, J. D. 2011. "The Incredible HOLC? Mortgage Relief during the Great Depression." Journal of Money, Credit, ANd Banking 43, no. 6 (September): 1073-1107.

Tracy, J., and J. Wright. 2016. "Payment Changes and Default Risk: The Impact of Refinancing on Expected Credit Losses.” Journal of Urban Economics 93 (May): 60-70.

Vandell, K. D. 1995. "FHA Restructuring Proposals: Alternatives and Implications." Housing Policy Debate 6, no. 2: 299-393.

Wheelock, D. C. 2008. "Government Response to Home Mortgage Distress: Lessons from the Great Depression." Federal Reserve Bank of St. Louis working paper no. 3008-038A, October.

The Economic Policy Review is published by the Research and Statistics Group of the Federal Reserve Bank of New York. The views expressed are those of the individual authors and do not necessarily reflect the position of the Federal Reserve Bank of New York or the Federal Reserve System. Economic Policy Review articles may be reproduced for educational or training purposes, provided they are reprinted in full; include credit to the author(s), the publication, and the Bank; and include the publication's disclaimer.

(C) 2018 The Federal Reserve Bank of New York 